\title{
Problematic Issues of E-Banking Management in Bangladesh
}

\author{
Md. Redwanuzzaman ${ }^{1} \&$ Md. Amirul Islam²
}

${ }^{1}$ Lecturer, Dept. of Business Administration, Pabna University of Science \& Technology

${ }^{2}$ Assistant Professor, Dept. of Business Administration, Pabna University of Science \& Technology.

\begin{abstract}
In Bangladesh, banking industry is getting mature to a great extent than earlier period. With the launching of internet the world has become a smaller one. Remarkable development in ICT has introduced a global revolution in banking sectors. Beside the every sector in social life it has rendered enormous impacts on banking sector. Internet together with other information and communication technologies are not only driving financial global economies but also transforming societies into knowledge-based economies around the world. As a third world developing country, Bangladesh is far behind to reach the expected level in global banking system. So it is our urgent need to upgrade its banking system. The main focus of this study is to examine the performance, problems and prospects of E-banking in Bangladesh. This paper is also aimed at to determine the present scenario of e-banking and banking sectors in Bangladesh and at the same time it demonstrated the scope and benefits of e-banking compared with the existing sector. The study is descriptive in nature. So this study has been done mainly based on secondary sources of data or information which sources included different published articles, books, newspaper, and websites.
\end{abstract}

Keywords: Electronic Banking, Bank, Bangladesh JEL Classification Code: G29

\section{INTRODUCTION}

$\mathrm{T}$ The banking sector occupies an important position in the global economy. The sector has been subject to many external and internal forces. Of the external forces, technological change is likely to have the most far-reaching impact on the sector. Technology, in particular the Internet, is a key driver of these changes. The emerging technology has made an exponential growth of the Internet which has changed the pattern of organizations performing their business with customers. The banking industry is no exception. Internet technology has brought a revolution in our conventional banking system. E-banking can offer speedier, quicker and dependable services to the customers for which they may be relatively satisfied than that of conventional system of banking. In order to gain competitiveness, banks have been introducing more internet banking services. The concept of e-banking includes all types of banking activities performed through electronic networks. It is the most recent delivery channel of banking services which is used for both business-tobusiness (B2B) and business-to-customer (B2C) transactions. However, in true sense, e-banking includes activities like payment of bills and invoices, transfer of funds between accounts, applying for a loan, payment of loan installments, sending funds to third parties via emails or internet connections regardless of where the client is located. The definition of e-banking varies amongst researchers partially because electronic banking refers to several types of services through which a bank customer can request information and carry out most retail banking services via computer, television or mobile phone (Daniel 1999; Molls 1998; Sathye 1999). On the other hand, Burr (1996) describes e-banking as an electronic connection between the bank and customer in order to prepare, manage and control financial transactions. In brief, e-banking is not a banking product or service; rather it explains the way transactions are conducted. Leow, Hock Bee (1999) state that the terms PC banking, online banking, Internet banking, telephone banking or mobile banking refers to a number of ways in which customer can access their banks without having to be physically present at the bank branch. Therefore, e-banking covers all these ways of banking business electronically.

\section{JUSTIFICATION OF THE STUdY}

E-banking is becoming an indispensable part in a global competitive free market. Only satisfying present need of customer cannot ensure the sustainability and expansion of banking business. Because a number of competitors may also work for satisfying the same customer need with superior customer value. Customers are increasingly demanding more value, with goods customized to their exact needs, at less cost, and as quickly as possible. Those who are giving much more services rather than others are giving; he will be well ahead of competition because of getting better competitive advantages. There are different 
Asian Business Review, Volume 3, Number 1/2013 (Issue 5)

ISSN 2304-2613 (Print); ISSN 2305-8730 (Online)

banks working together in Bangladesh. The competition is going up day by day by giving better services and they are trying to develop their own services every now and then. To meet these demands, businesses need to develop innovative ways of creating value which often require different enterprise architectures, different IT infrastructures and different way of thinking about doing business. This transformation of business from an old company to a new agile electronic corporation is not easy and requires a lot of innovative thinking, planning and investment. Many banks and other organizations have already implemented or are planning to implement ebanking because of the numerous potential benefits associated with it. So, Electronic banking has got tremendous importance in banking sector and banking customer as well. This is why, it finds some interest to explore many of these issues regarding e-banking in some extent.

\section{Methodology}

The study is descriptive in nature. Data used in this study are collected basically from the secondary sources. For this purpose, different recognized journals, government rules and regulations, policies have been discussed. Various seminar papers and summary of discussions in those seminars, taskforce report of research organizations and some periodicals, national and international journals, newspapers, magazines, Bangladesh Bank publications, published articles, books, newspaper, and websites have been surveyed. Some primary data are also collected through personal interview method conducting the persons who are supposed to have knowledge about the problem. Some bank specialists have also been personally interviewed in order to collect some primary information used in this study. Besides this, internet has been used as another source of information.

\section{ObJectives of the Study}

The main objectives of this study are as follows:

1. To examine the scope and prospects enabling E-banking in Bangladesh.

2. To demonstrate the benefits and problematic issues of Ebanking

3. To present the possible services rendered by E-banking

4. To overview the managerial challenges of E-banking in Bangladesh.

5. To suggest measures for growth of E-banking in Bangladesh.

\section{Scope of Electronic Banking in Bangladesh}

The infrastructure of a country is very important for implementing electronic banking. For electronic banking major cost is to set up backbone network. Fortunately Bangladesh Railway has a high-speed optical fiber network parallel to the railway path owned by Bangladesh
Railway. Its total capacity is about 2.5 gigabits per second. This fiber optic network covers almost every important parts of the country (Islam, 2005). Bangladesh has been connected with the information superhighway on 20th May, 2006. It is a landmark of ICT sector of Bangladesh. The cable network covering some 786 miles across the country from the Bay of Bengal will provide a fiber-optic link with a data transfer capacity of 10 gigabits per second compared to the 150 megabits per second bandwidth now used by the state owned BTTB and dozens of private Internet Providers. The growth of Internet users of our country is rapidly increasing day by day in Bangladesh.

\section{Prospects of Electronic Banking in BANGLADESH}

The Bangladesh railway owned a high-speed optical fiber network $(1,800 \mathrm{~km})$ parallel to the railway path that covered most of the important parts of Bangladesh. This optical fiber network can be used as the backbone network of e-banking in Bangladesh. For example, mobile phone operators such as Grameen Phone and Ranks ITT of Bangladesh used this optical fiber network through which they reached even in rural areas with their services (Islam 2005). It is encouraging that some of the FCBs and PCBs are already used this optical fiber network for conducting online transactions, ATM and POS services. In addition, Bangladesh Bank was implementing the

different projects for modernizing national payment and settlement system started from 2009 followed by the development of inter-bank online network. It made mandatory for all head offices of the scheduled banks to be connected with Bangladesh Bank. These efforts would allow the scheduled banks to be connected to each other for conducting inter-bank online transactions in near future and this would smooth the introduction of e banking in Bangladesh. Internet services came to Bangladesh with connectivity in 1996. Digital telephone exchanges established in 389 upazilas and 17 growth centers. Work was underway to cover the rest of the upazilas under digital exchange system. Meanwhile, Bangladesh joined the information super-highway by connecting itself with international submarine cable system in 2006. A total of 159 Internet Service Providers (ISPs) now connected with this system of which 64 are actively providing services. Internet connection was slow with bandwidth range 32 - $56 \mathrm{kbps}$ for dial up and 64 - $8 \mathrm{Mbps}$ for broadband. Under this scenario, as a part of government decision of building digital Bangladesh, the existing capabilities of ICT sector was likely to increase rapidly in bringing all upazilas under internet services and this will contribute in widening the scope of ebanking throughout the country. The overall computer density in the banking sector was 1.64. For foreign commercial banks (FCBs) the computer density was 45.34, where as for NCBs the ratio was only 0.41 . The specialized bank scenario was almost same as the NCBs, 0.43 . On the other hand, private commercial banks had comparatively 
higher ratio, 4.94. As a whole 81.81 percent bank did not have any local area network (LAN), 30 percent had WAN (Wide Area Network) but for some banks many branches were outside of WAN connectivity. At present, all foreign banks of our country were using online banking system; they were invested a lot for their automation banking services. For this reason, they were increasing market share every year. They were the pioneer of implementing electronic banking systems in Bangladesh, but now most of the private banks of our country used electronic banking systems. In our country different banks were offering electronic banking services in different ways, some were offering ATM (Automatic Teller Machine) services, some were tele-banking and some were electronic fund transfer, debit card, credit card, etc. Recently, the government's emphasis on building a digital Bangladesh, setting up ICT park, raising allocation for developing ICT infrastructure, waiving taxes on computer peripherals and other measures including the automation program of banking sector led by the Bangladesh Bank and competition among the scheduled banks in improving customer services accelerated the prospects of e-banking in Bangladesh.

\section{BeNEFITS OF E-BANKING}

E-banking is a significant investment, so the question must be answered as to what motivates banks to participate and deal with the associated problems and risk. This article summarizes some of the benefits often associated by banks to be their primary motive for implementing e-banking. Ebanking has helped many banks to realize benefits, which are summarized bellows:

- Choice and Convenience for Customers

- Attracting High Value Customers

- Accounts Aggregation

- Enhanced Image

- Increased Revenues

- Easier Expansion

- Load Reduction on Other Channels

- Cost Reduction

- Organizational Efficiency

- E-Marketing

The nature of e-banking means that personal contact between customers and banks are eroded. Harden (2002) suggests that e-channels erode a direct relationship with customers as compared with traditional over-the-counter banking: e-banking does not offer face-to-face contact in what is essentially a one-to-one service relationship. To compensate, e-banks must deliver higher quality services in order to compete with other service delivery channels (Liao \& Cheung, 2005). Another factor in the loss of personal relationships is the convenience of Internet shopping: it is much easier now to compare products and switch between different providers. This creates the need for offering high value products and to cut operational costs to remain competitive, which in turn may further erode the avenues for building personal relationships with customers. The solution to these problems appears to be offering a multi channel experience which is better than direct competitors. E-banking often attracts high profit customers with higher than average income and education levels, which helps to increase the size of revenue streams. For a retail bank, ebanking customers are therefore of particular interest, and such customers are likely to have a higher demand for banking products and an interest in more complex (and even riskier) products.

Another benefit of e-banking from a customer's point of view is that most banks provide accounts aggregation services, at least internally. Accounts aggregation enables a consumer to be presented with all his or her account details (current account, saving account, mortgage account) on a single page. E-banking helps to enhance the image of the organization as a customer focused innovative organization. This was especially true in the early days when only the most innovative organizations were implementing this channel. Despite its common availability today, an attractive banking website with a large portfolio of innovative products still enhances a bank's image. This image also helps in becoming effective at e-marketing and attracting a young/professional customer base.

Increased revenues as a result of offering e-channels are often reported, because of possible increases in the number of customers, retention of existing customers, and cross selling opportunities.

Traditionally, when a bank wanted to expand geographically it had to open new branches, thereby incurring high start up and maintenance costs. E-channels, such as the Internet, have made this unnecessary in many circumstances. Now banks with a traditional customer base in one part of the country or world can attract customers from other parts, as most of the financial transaction does not require a physical presence near a customer living/working place.

E-Channels are largely automatic, and most of the routine activity such as account checking or bill payment may be carried out using these channels. This usually results in load reduction on other delivery channels, such as branches or call centers.

The main economic argument of e-banking so far has been reduction of overhead costs of other channels such as branches, which require expensive buildings and a staff presence. It also seems that the cost per transaction of ebanking often falls more rapidly than that of traditional banks once a critical mass of customers is achieved.

To implement e-banking, organizations often have to reengineer their business processes, integrate systems and promote agile working practices. These steps, which are often pushed to the top of the agenda by the desire to achieve e-banking, often result in greater efficiency and agility in organizations. However, radical organizational changes are also often linked to risks such as low employee morale, or the collapse of traditional services or the 


\section{customer base.}

E-marketing in the financial services sector (which is covered later) was made possible by the arrival of e-banking. Emarketing builds on the e-channel's ability to provide detailed data about customers' financial profiles and purchasing behavior. Detailed understanding of customers enables customized advertising, customized products (called mass customization) and enrichment of the relationship with customers through such activities as cross selling.

\section{Problematic Issues Related E-Banking}

The implementation of a successful e-banking strategy in Bangladesh is far from being straight forward, as there are numerous inherent difficulties/barriers. The Internet as a channel for services delivery is fundamentally different from other channels such as branch networks or telephone banking. Therefore, it brings up its own unique challenges that Bangladeshi banks require innovative solutions. Thus, a logical step for the management of banking related organizations may be to fully understand the organizational barriers inherent in e-banking. The Internet has not only created previously non-existent opportunities for cost effective, all time available financial services, it has also increased the significance of a number of risks which did not exist or were not significant in the past. Furthermore, a number of change management issues usually associated with any new technology implementation are compounded simply because some applications such as e-banking have a greater and more immediate impact on the organization. This article has viewed some of the most common problematic issues of Bangladesh in e-banking implementation and management. The main focus will be on those issues which pose considerable risks to e-banking projects and may prevent banks from achieving their desired e-banking related goals. These include: traditional structures which some banks still have and which are unable to respond to agility required for e-banking, resistance from employees, legacy systems which are an obstacle to the integration of systems, security issues, new and complex regulatory issues, and project management problems.

\section{Possible Services Rendered by E-Banking}

In its very basic form, e-banking can mean the provision of information about a bank and its services via a home page on the World Wide Web (WWW). A more sophisticated Internet based service provides the customer with access to their accounts, the ability to move money between different accounts, make payment or apply for loans and other financial products. The term e-banking has been used in this article to describe all types of provision of financial services rendered by an organization to its customers. Such customers may be an individual or another business. In the context of ebanking, electronic delivery of services means a customer conducting his transactions from a remote location (e.g. home) rather than visiting a local branch. Internet only banking may also become more viable as the functionality of e-banking systems grows, and customers adapt to the new ways of conducting their financial activities. E-banking largely came into being as a result of technological developments in the field of computing and communications but there have been a number of different types of possible availed e-banking services like account access, balance transfer, bill payment, bill presentment, mortgage/credit card/ misc. lending, business banking services, customer service \& administration, cross-selling, personalized content and tools, accounts aggregation and electronic funds transfer which played an important role in its development.

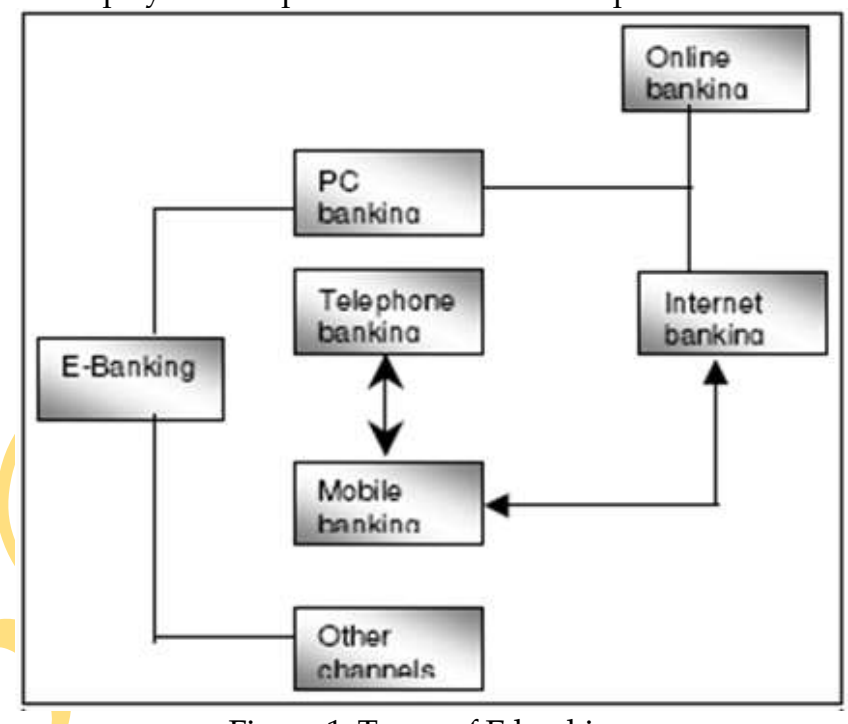

Figure 1: Types of E-banking

\section{Management Challenges}

The management challenges for Bangladeshi banks are mainly fourfold. First, they need to satisfy customer requirements that are complex and ever changing. Second, they need to deal with increased competition from old as well as new entrants coming into the market. Third, they need to address the pressures on the supply chain to deliver their services quickly. Finally, they must continually develop new and innovative services to differentiate themselves from the competition, as having a large branch network is no longer seen as a main source of competitive advantage. So, these challenges for banks surround increased customers expectations, security problems, technological challenges, Echannels specific marketing, change management, project management, winning customer trust, human resources management, managing external relationships marketing \& sales and regulations management.

E-banking is seen by many Bangladeshi banks as a key tool to address these challenges. Other reasons for the adoption of e-banking by banks may include achieving competitive advantage (at least in short term), creating new distribution channels, improving image, and reducing costs.

It is widely acknowledged that complexity in the managerial environment has increased because e-services often require decisions that focus on integration of internal/external systems, adoption of new business models and frequent 
restructuring of existing business processes and structures. The Internet also impacts market structure, and affects competitive advantage in the banking sector.

\section{Recommendations}

In order to ensure a successful practice of e-banking in Bangladesh, it recommends the following.

- To develop Strategy in order to fully utilize opportunities and minimize threats.

- To design integrated channels this will enable to achieve the operational efficiencies.

- To establish flexible management system to examine new processes designed specifically for e-Commerce.

- To adapt flexible organizational model so that it compete with Start-Ups.

- To promote innovation culture as to encourage individuals as well as teams to innovate.

- To leverage existing brand to deliver new services to perceive lack of security and fraud threats.

- To reinforce "Trust Relationships" to construct involving security and privacy issues on the Internet.

- To offer universal product (not just own products) to have access to a wider range of financial services.

- To make highly secure, robust environment for developing suitable business continuity plan.

- To manage resistance to change to minimize complex issues for acceptance.

- To Manage technological issues with care for unified messaging system.

- To establish e-channels specific marketing to decline switching barriers.

- To identify employees with skills different from those found in more traditional organizations.

\section{Concluding Remarks}

Modern electronic banking concept in the banking services is new for Bangladeshi people. Most of our bank has not any marketing or sales forces to execute the raw and cold business of electronic banking for their own organization. People are not also conscious about the advantages of the technology. Some multinational banks are already introduced their marketing activities over their targeted customers for specialized products like electronic products which is found very effective. The multinationals are coming up towards people with variety of highly technical products, which can solve people's problem and can able to modernize their lifestyle. The growth of electronic banking users increasing is a significant manner. However, last 10 years it has got tremendous importance over the bank customer and hopefully it will increase day by day after nurture the product by the professional bankers.

\section{REFERENCES}

Avkiran, N. K. (1999). Quality Customer Service Demands Human Contacts. International Journal of Bank Marketing, 17(2), 61-71.

Abdullah S.Al Mudimigh (2007) E- Business strategy in an online banking services, A case study, vol-12,No-1,pp1-6.

Chai, Lee Goi (2006) Factors Influence Development of EBanking in Malaysia, , Journal of Internet Banking and Commerce, vol. 11, no.2

Islam, Anwarul, et.al(2006) Growth and development of information and communication technologies in Bangladesh, The electronic library,Vol.24,no.-2, pp-135-136

Daniel, E. (1999), Provision of electronic banking in the UK and the Republic of Ireland, International Journal of bank marketing, Vol. 17, No. 2.

Islam, M. (2005), Proposed IBT infrastructure for E-banking in Bangladesh, Master of Science Thesis, Royal Institute of Technology (KTH), Stockholm, Sweden.

Mia, Rahman and Uddin, (2007), E-banking: Evolution, Status and Prospects, The Cost and Management, Vol.35, No.1, January-February 2007, pp. 36-48.

Adcock, K., Helms, M. M., et al. (1993). Information Technology: Can it provide a sustainable competitive advantage? Information Strategy: The Executive's Journal, 9(3), 10-15.

Bareil, C. (2002). Managing Resistance to Change or Readiness to Change? http://web.hec.ca/sites/ceto/fichiers/04_02.pdf

E-banking in India - major development and issues, by S. S. Debashish and B.P. Mishra- Pranjana, vol. 6, no.1, Jan July 2003, pg 19

Aladwani, A. (2001). Online banking: a field study of drivers, development challenges and expectations." International Journal of Information Management, 21(3),213-25.

Beer, M., \& Nohria, N. (2000). Cracking the Code of Change. Harvard Business Review, (3), 133-141.

Adamides, E. D., \& Karacapilidis, N. (2006, January). Information technology support for the knowledge and social processes of innovation management. Technovation, 26(1), 50-59.

Adamides, E. D., \& Karacapilidis, N. (2006, January). Information technology support for the knowledge and social processes of innovation management. Technovation, 26(1), 50-59.

Amato-McCoy, D.M. (2006, February 27). Planning for continuity. Bank Systems \& Technology.

Clarke, A., Ensor, B., \& Camus, L. (2008, April 15) Investors Don't Understand The Importance Of Online Advice Tools. Retrieved on November, 12, 2008 from www.forester.com

$$
--0--
$$

